\title{
The Volatility of the 'Other': Identity Formation and Social Interaction in Diasporic Environments
}

Laurent Gayer

\section{OpenEdition}

\section{Journals}

\section{Electronic version}

URL: http://journals.openedition.org/samaj/36

DOI: $10.4000 /$ samaj.36

ISSN: $1960-6060$

\section{Publisher}

Association pour la recherche sur l'Asie du Sud (ARAS)

\section{Electronic reference}

Laurent Gayer, «The Volatility of the 'Other': Identity Formation and Social Interaction in Diasporic Environments », South Asia Multidisciplinary Academic Journal [Online], 1 | 2007, Online since 15 October 2007, connection on 19 April 2019. URL : http://journals.openedition.org/samaj/36 ; DOI 10.4000/samaj.36

This text was automatically generated on 19 April 2019

\section{$(1) \Theta \Theta$}

This work is licensed under a Creative Commons Attribution-NonCommercial-NoDerivatives 4.0 International License. 


\title{
The Volatility of the 'Other': Identity Formation and Social Interaction in Diasporic Environments
}

\author{
Laurent Gayer
}

1 The construction of inimical figures lies at the heart of identity formation processes. This postulate can bring together political scientists and anthropologists alike. The former will discern here the friend/foe dialectics in which nationalism originates (Jaffrelot 2003). The latter will interpret this process in terms of ethnic boundaries formation (Barth 1969). Whatever concept social scientists may use to refer to this construction of the 'other', they all agree on its crucial role in the formation of 'ethnic groups', this term referring to 'all the groups of a society characterized by a distinct sense of difference owing to culture and descent' (Glazer \& Moynihan 1975: 4). Therefore, 'From its beginning, the term ethnicity has been one concerned with opposition, on the nature of difference between antagonistic groups' (MacClancy 1996: 9). Yet, the specificities of ethnic relations in diasporic environments remain understudied and social scientists are still too inclined to relate diasporic communities to a single 'other': their host state and society. This analytical myopia leads to an obliteration of all the other 'others' of migrant communities, ${ }^{1}$ whether in their country of residence or in their home state. The deterritorialization of such communities and their transnational-or rather translocalnetworks put them into actual or virtual contact with a wide range of actors, amongst whom several may be eligible for the title of 'other'. Thus, enlarging the spectrum of analysis has become urgent for social scientists concerned with diasporas, their identities and their mobilizations. It is to that heuristic leap forward that I would like to contribute here, through a theoretical discussion based on my fieldwork in the UK (Gayer 1998).

Constructions of the 'other', in diasporic environments, have two major attributes: their multiplicity and their volatility. Ethnic entrepreneurs have a wide range of options to propose an 'enemy' to their audience, hence their multiplicity. At the same time, social 
and political evolutions in the migrants' country of residence or in their home state make such constructions of otherness highly contingent. The study of ethnic relations in diasporic environments is thus a difficult task and very little empirical material is presently available on this critical issue. But before looking at social and political relations between 'diasporic communities', it is necessary to define this elusive notion which social scientists have become accustomed to use in a rather loose way.

\section{Defining diasporas}

Among the Jews, the Hebrew term 'galout' (exile) evokes the nostalgia of origins, whereas the Greek term 'diaspora' is related to a specific and critical event: the dispersion of the Jewish community after the destruction of the Temple of Jerusalem and the annexation of Judea by the Romans. Even if the term 'diaspora' appeared for the first time in Thucydides' War of the Peloponnesus to describe the scattered Greeks (Sheffer 2003: 9), it has remained associated with the Jews until the $16^{\text {th }}$ century. In French, this singularity of the Jewish condition was emphasized by the spelling of the term, which started with a capital letter. However, between the $17^{\text {th }}$ century and the 1960s, this term has become more banal and it was progressively attributed to the Greeks, the Armenians and the Chinese. Throughout this period, the term 'diaspora' designated 'the condition of geographically dispersed people, who were mobilized by different political organizations and who, in spite of their dispersion, retained a form of unity and solidarity' (Schnapper 2001: 9). But since the end of the 1960s, the semantic field of the term has widened and it has been applied to every group of dispersed people, from expatriates to refugees and from immigrants to activists in exile. This indiscriminate use of the term is particularly pronounced since the 1980 s and may be explained by the crisis of assimilation policies and the subsequent rise of the politics of diversity in western host states (Shuval 2003). This semantic confusion, which originates from new perceptions of migrant ethnicities, has made the use of the term highly problematic, because it now refers to extremely diverse processes and because it is often used in a metaphorical way (Marienstras 1989, Safran 1991, Skinner 1993). The historicity of the diasporic condition has also blurred: by looking at diasporas in the longue-durée, geographers and sociologists often fall prey to what Stéphane Dufoix has called a 'fixing illusion', which postulates 'the a-historicity, the permanence of transnational communities through the ages (...) without fundamental changes in their modes of organization, as if their existence was somehow natural' (Dufoix 1999: 151).

4 The term 'diaspora' now implicitly postulates the existence of intangible links between dispersed people and their homeland, although such links, which have to be constructed and nurtured, take a variety of forms in time and space. This dynamic dimension of diasporic identifications had been emphasized by early pioneers of diasporic studies, such as Gabriel Sheffer (1986). However, analysts of diasporas now tend to neglect this dynamics, by taking the existence of Armenian, Chinese or Indian diasporas for granted. Social links between these diasporas and their homelands thus become reified, since every emigrant or political exile is supposed to belong to the diaspora. At the same time, the identifications of these dispersed peoples become a-historical, since diasporic consciousness seems to be unchanging.

5 To break away from such reifications, diasporic studies have to acknowledge present changes in the circulation of people, ideas and funds while questioning the historical 
trajectories of these evolutions. Beyond this quest for historicity, diasporic studies must rely on solid definitions of the term 'diaspora' itself. Political sociology and social anthropology can both help us to ground this definition in solid theoretical premises. Informed by historians, political sociologists have shown us that traditions are modernized, sometimes even invented. Social anthropologists, for their part, have taught us to look at culture as a process rather than a substance. By trying to bridge the gaps between these two disciplines which have engaged in a fruitful dialogue in the last decade or so, I will here define diasporas through their patterns of formation, interaction and mobilization, i.e. through their identity politics rather than through their morphological properties. I tend to see diasporas as translocal social groups which, under certain circumstances, fashion a common identity for their members, distinct from that of their host and home societies. This distinct identity is based on memories of a temporally and geographically distant past which are reconstructed to suit the needs of the present. In other words, diasporas are self conscious and politically organized mnemonic communities. Their members are brought together by shared memories of their (even mythical) homeland and they ground their lives in a translocal space which may be partially virtual. Like every other social group, diasporas also ground their identities in constructions of otherness, both internal (fixing the boundary between 'proper' and 'incorrect' behaviours inside the community) and external (fixing the boundaries between the community and its social partners). These translocal populations have a wider range of options than more territorialized communities in this regard. Moreover, as I have already suggested, diasporic constructions of otherness present a high volatility due to the plurality of factors affecting them, in the translocal space where they evolve.

6 To avoid the reifications which are all too often associated with conceptualizations 'from above', I will look at Indian and Pakistani diasporas 'from below', through everyday lives of Indian and Pakistan migrants in the UK, particularly in the West London area where I have done most of my fieldwork related to overseas Indians and Pakistanis. This urban space is not a 'locality' in the traditional sense but one place of experience among others for the populations which inhabit it. To comprehend such a translocal space, I travelled to various locales, from Indian Punjab to British Columbia. My experience of fieldwork was therefore multi-local and trans-local, in that I tried to clarify the nature of relations between several political localities. ${ }^{2}$

\section{Volatile identities: constructions of otherness among overseas Indians and Pakistanis in Southall, UK}

7 South Asian migrants have not been immune to the popularization of the term 'diaspora' during the last two decades. The renewed interest of Indian authorities for their expatriates and their growing political clout, particularly in the US, have recently contributed to a proliferation of publications on the Indian diaspora (Jayaram 2004, Parekh et al. 2003). Some authors prefer to talk of a 'South Asian diaspora', even if they rarely precise what they mean by that, making this phrase synonymous with 'South Asian overseas' (Vertovec 1991). If some authors inscribe the Indian diaspora in a larger diasporic formation, others undermine these theoretical constructions by talking of a Hindu (Vertovec 2000) or a Sikh diaspora (Barrier \& Dusenbery 1989, Tatla 1999). Surprisingly, Pakistani migrants have not received the same attention from analysts of diasporas and only a handful of anthropologists have studied the Pakistani diaspora. ${ }^{3}$ 
If I stick to the definition of the term 'diaspora' I proposed above, overseas South Asians are clearly not eligible for this title. Overseas Sri-Lankans and overseas Indians, Pakistanis and Bangladeshis do not share a homeland, nor do they have common memories. Moreover, these migrants do not circulate in the same translocal space. On the contrary, the new politics of identity of some Indian overseas communities, particularly in the US, and the renewed interest of the Indian state for its prodigal son have now turned the Indian diaspora into a socio-political reality. The same cannot be said of the Pakistani diaspora, which is yet to turn into an established social fact. However, the specific identifications, modes of socialization and political orientations of overseas Pakistanis and the emergence of a new blend of explicitly Pakistani ethnic entrepreneurs during the last decade or so justify the use of the term. I will therefore refer to Indian and Pakistani diasporas throughout this paper, even if I believe that the term can also be applied to the Sikhs and to the Kashmiris living abroad, at least since the last two decades, during which these minorities in the larger Indian and Pakistani diasporas have developed singular identities and patterns of organization in relation to the political turmoil affecting their homeland. The transformation of overseas Sikh and Kashmiri communities into diasporas illustrates vividly the volatility of constructions of otherness among overseas South Asians. Political turmoil in the homeland or socio-economic conflicts in the country of residence may trigger conflicts between these diasporas; they may also create dissensions within their ranks, by fuelling fissiparous tendencies.

These communal tensions can vary greatly from one country to another. Although it is often assumed that identities of South Asian migrant communities are largely 'brought with them', and that they are 'based upon primordial and age-old forms of identity to be found in the Indian subcontinent', the conflicts between these communities are not inevitable or natural. Indeed, as Crispin Bates (2001: 3) suggests, 'the boundaries of 'communities' and their relations with neighbours of other communities, and the political articulation of these relationships, can vary enormously'. Divergent social and historical circumstances have produced different patterns of community relations in every settlement of overseas South Asians. Such divergences are manifest at the national level but also at the local, neighbourhood level.

To illustrate this volatility of the 'other' in the Indian and Pakistani diasporas, I have chosen to focus my analysis on a neighborhood of west London: Southall, the 'capital town of South Asians in Britain' (Baumann 1998: 38). In the 1920s, this industrial suburb was populated by English and Irish labourers. In the 1950s, this workforce was replaced by Indian and Pakistani emigrants, largely of Punjabi origin. The presence of industrial plants in the area and the proximity of Heathrow Airport provided these migrants with numerous job opportunities and most of them expected to return to their homeland after a few years. Reforms in British laws regulating immigration put an end to this myth of return and led these early migrants to bring their families with them. During the 1970s, the presence of South Asians in the area became even more visible with the arrival of Indian refugees from Kenya (after 1967) and Uganda (1972).

11 The contiguity of Indian and Pakistani migrant 'communities' in the neighbourhood makes Southall a place of special interest for studying the relations between these diasporic populations. The ethnic diversity of Southall is exemplified by table 1 , which shows 'Indians' in a hegemonic position and 'Pakistanis' in that of a minority. Among the 'Indians', Hindus are a minority: the proportion of Sikhs in the local South Asian 
population varies from $40 \%$ across the town as a whole to $60 \%$ in the central wards (Baumann 1998: 73).

Table 1 - Ethnic origins of Southallians (1991)

\begin{tabular}{|l|l|}
\hline Category & $\%$ \\
\hline 'Indians' & 50 \\
\hline 'Pakistanis' & 7 \\
\hline 'Other Asian' & 3 \\
\hline 'White' & 30 (of whom one in ten was born in Ireland) \\
\hline 'Black Caribbean' & 5 \\
\hline Other categories & 5 \\
\hline
\end{tabular}

SOURCE: BAUMANN 1998: 48

\section{The ties that bind: Southallian attempts at transcending national and religious cleavages}

At first sight, social harmony seems to prevail in multi-religious Southall. As Gerd Baumann (1998: 46) suggests, 'Stereotyping and sometimes disdain of neighbours from different communities is by no means rare. Yet there is the strictest censure on declared or open enmity. The make-up of the population is varied enough for everyone, on the surface at least, to pretend to 'get on well with everyone'. The public tone is polite'.

When South Asian migrants started settling down in Southall, this idyllic portrait of community relations was not very far from the truth, even if such representations of the neighbourly relations between South Asian immigrants should be treated as a political and normative discourse which depicts the way these populations should live together rather than their actual neighbourly relations. Such discourses should be taken seriously, though. However normative they may be, these representations are performative: they change the world they claim to represent. And however utopian they may seem to be, these performative declarations are grounded into a certain reality, which should be questioned rather than rejected altogether.

In the 1950s and 1960s Indians and Pakistanis did not have any hostility for each other and the memories of Partition did not prevent them from joining the same associations, such as the Indo-Pakistan Cultural Society. Trade unionism was also a strong bind. Although the hegemonic local trade-union was the communist-dominated Indian Workers' Association (IWA, founded in 1956), it accepted Pakistanis as associate members. Beyond trade-unionism, anti-racism also brought Southallians together throughout the 1960s and 1970s, which saw the rise of the British National Party (BNP) in local councils. During this period, Southall experienced several disturbances that the local media presented as 'race riots'. The worst of these incidents took place on 23 April 1979, when a demonstration of the National Front led to clashes between skin-heads and left-wing 
activists which resulted in the death of Neo-Zealander teacher named Blair Peach. Left politics was then building bridges between South Asians of all caste and creed. But this rapprochement was also based on a shared popular culture, which has been reinvented in the diasporic context.

Most South Asian inhabitants of Southall originate from the Punjab and share the same language. Beyond language, Punjabis of all caste and creed share a common imagination, based on folk tales, poetry and songs. This popular culture fashions common attitudes, assumptions and practices, so that wherever they reside, 'Punjabis willingly, and indeed proudly, identify themselves as such, regardless of whether they might otherwise be classified as Hindus, Muslims or Sikhs, and regardless of whether they hold Indian, Pakistani, British, United States, Canadian or any passport' (Ballard 1999: 12). Yet, Punjabi identity (Panjabiyat) has been undermined by the communal reconstruction of religious communities in the Punjab during the $19^{\text {th }}$ and $20^{\text {th }}$ century and even more so by Partition, to such an extent that historian J.S. Grewal (1999: 52) has suggested that 'the shattered mirror of Punjabi consciousness reflects tiny images, which refuse to coalesce into a portrait'. In the diaspora, the events of the last decades have also contributed to the weakening of pan-Punjabi identifications. During the 1950s and 1960s, Punjabi immigrants found some comfort in the proximity of other Punjabis, regardless of their caste and creed: 'family connections, or affiliations of region, language, dress, and culture proved to be a comfort in a still deeply stratified and discriminatory London' (Shukla 2005: 92). However, in the following decades, these supranational linkages became less appealing to 'Indian' and 'Pakistani' Punjabis. Paradoxically, while they started taking roots in an increasingly multicultural London, these populations were also 'reclaimed' by their national homelands, to use the words of one of my (Sikh) informers. This is not to say that they were naturally inclined to 'go back to their roots', but rather that they started feeling confident enough in their new diasporic environment to reconstruct their identity by emphasizing their differences, both inwardly (in order to set themselves apart from other 'Indians' and 'Pakistanis') and outwardly (in order to dissociate themselves from other, less successful, ethnic minorities but also to publicize their difference from an 'English' society which was still resenting the presence of its former colonial subjects in the backyard of the metropolis).

It is in this context that political turmoil in the homeland came to affect patterns of community relations in the diaspora, external changes being mediated by the transformations of the local context. Therefore, armed conflict in the Indian Punjab did not impulse the communalization of overseas Sikhs but only accelerated an ongoing process of differentiation between Punjabi Sikhs and Hindus, whose interactions became less frequent after operation Bluestar and the anti-Sikh pogroms of 1984. This estrangement of Hindu and Sikh populations tends to be undermined by Hindu Southallians, who often denounce the brutality of Operation Bluestar and emphasize the shared culture of all Punjabis in order to bring the Sikhs back into the Indian fold. This (re-)integrative discourse is reminiscent of the attempts made by Hindu nationalists to reclaim the Sikhs as Hindus. However, in multireligious Southall, this discourse does not derive from a project of assimilation by the Hindu majority but, rather, from an attempt to preserve communal harmony and to defend the 'common world' bringing together each and every Southallian of Punjabi descent. One of my informers, working as a journalist for the local Desh Pardesh (whose editor was murdered by the Khalistanis) thus told me: 'The attack on the Golden Temple was a very painful event that History can't 
forget or forgive. It was a historical blunder. Even Hindus feel the same. No religious place should be attacked by the army. But Hindus and Sikhs are the same, they are still closely related. The moderate Sikhs and Hindus realize that this was a mistake and that it shouldn't be kept in the minds, otherwise it will vice the atmosphere'. ${ }^{4}$

The end of militancy in the Indian Punjab has opened a new political space for Punjabi nationalists in the diaspora and some Khalistani cadres of the preceding decades have dropped the Khalistan issue to promote 'Panjabiyat'. This is particularly true of the Sikh nationalists who mobilized the Khalistan Council around Jagjit Singh Chauhan, the main ideologue of the Khalistan movement, who settled in Britain at the beginning of the 1970s. Although Chauhan himself returned to India in 2001, his aides did not disengage from politics and they have recently set-up a lobby called 'Punjabis in Britain', patronized by the Labour M.P. for Hayes and Harlington, John McDonnell. ${ }^{5}$ One of these former Khalistanis has also launched an NGO, the Panjabi Center, which addresses Punjabis of all caste and creed. It remains to be seen if such initiatives can appeal to Punjabi Hindus and Muslims, who tend to see Punjabi nationalism as a Trojan Horse taking forward the agenda of Sikh nationalists. In any case, the reinvention of former Khalistanis as Punjabi nationalists attests of the volatility of community relations in Southall and reveals the superposition of identifications which characterize its inhabitants, who do share a Punjabi identity but who have seen it undermined by communal conflicts in India, by the Indo-Pakistani inter-state rivalry and by periodic episodes of tension in the diaspora itself.

Cultural and political identifications of South Asian Southallians are highly complex and volatile, which makes the characterization of community relations in the area a rather difficult task. One group, in particular, presents extremely ambivalent tendencies regarding the modes of identification and mobilization of its members: the second generation. Contradictory trends have emerged among these youths during the last two decades. Amongst the most privileged sections of this age-group, particularly those with a university degree, a pan-ethnic movement promoting the redefinition of Indians, Pakistanis and Bangladeshis as 'Asians' has met with some success. However, as in the U.S., this pan-ethnicity has been opposed by communal elements, who have also taken roots amongst the youth. In Southall, some of these communal elements turned violent, mixing gang culture with religion to assert their violent masculinities. The political divide between the youths of the second generation is not only class-based, though. Even if the members of the 'gangs' of west and northwest London were generally unemployed and came from the most underprivileged strata of the 'Asian' community, Islamist associations (such as the Jama'at-i Islami, known in Britain as the Islamic Foundation) and their Hindu and Sikh counterparts tend to recruit their members in the upper strata of this population, particularly in universities. Although this was for very different motives, communalism has therefore appealed to the youths at the two extremes of the social ladder, whereas the pan-ethnic 'Asian' movement has primarily found support in the most privileged sections of the second generation. Yet, if the most privileged sections of the second generation have been the backbone of the 'Asian' socio-political movement, in a rather abstract and literary way, it is in mixed working-class suburbs such as Southall that the 'Asian' culture is lived and consumed with the greatest intensity, through cinema, music, food and sports. 


\section{The diasporic reinvention of communalism: 'religious' conflicts in Southall}

19 If Southallians, like other inhabitants of South Asian ethnic enclaves in the UK and North America, ${ }^{6}$ share a common popular culture transcending ethnic and religious boundaries, they are not immune to communal tensions. As in the subcontinent, communal conflicts are both punctual and selective in their appeal: they are activated by symbolic events and only mobilize a small number of actors, mainly suburban unemployed young males. ${ }^{7}$ These communal tensions are at their highest during religious festivals (Diwali for the Hindus, Baisakhi for the Sikhs and Eid for the Muslims) but also during cricket matches between India and Pakistan. However, as the case of cricket vividly illustrates, religious and sportive events are irreducible to politics, or rather, they are prone to multiple and conflictive political interpretations. As we shall see now, cricket is not inherently a factor of communal tensions between overseas Indians and Pakistanis. If the game has been appropriated by young chauvinistic street fighters, it has also been a source of inspiration for pan-ethnic peace-builders. And although youth 'gangs' disrupted communal relations by investing cricket with war-like attributes, they also bridged ethnic boundaries by playing the same game as their 'other', having fun in antagonizing him.

As Ashis Nandy (2000: xvi) suggests, 'cricket is a religion in South Asia'. So much so that a well-known humorist once noted about the Indians that 'For six months in a year they watch cricket and for the next six, they talk about it' (Krishna 1982). The game arouses the same passions among South Asians living abroad. However, the stakes are higher in the 'diaspora', since every important match between South Asian nations has the potential to trigger conflicts between local South Asian communities. Indeed, if the Shiv Sena tried to prevent the Pakistani Team from visiting India in 1999-by threatening the Pakistani players, among other things, to infiltrate cobras in their hotel rooms (Khan 2005: 24)-violent incidents are rather rare during cricket matches in South Asia. ${ }^{8}$ On the contrary, in the diaspora, the contiguity of Indian and Pakistani communities leads to frequent clashes, particularly between local youth 'gangs'. For these urban depraved youths, cricket has lost its gentlemanly connection and has become a more plebeian game, through which they may express their long-distance nationalism and their social frustrations, while defending or extending their 'territory' and the various unlawful activities which they may control inside it. For these playful and aggrieved youths, cricket has become a new bodily language, infused with politics of identity and economic rationalities. In the words of anthropologist Pnina Werbner (1996: 94-5), it has become 'an expression of controlled masculine aggression and competitiveness' and a popular expression of modern nationalism.

21 The 'communal' incidents that regularly disturb Southall during important matches between Indian and Pakistani teams epitomize this manly but not so gentle reinvention of cricket. Like in every other South Asian suburb in the UK, these matches are accompanied by public performances, with (mostly male) youngsters waving flags and hooting their horns to make their presence felt in the neighbourhood and to provoke their adversaries. These demonstrations may turn violent when the demonstrators cross 'hostile territories' or run into a group of opponents. Anticipating trouble, shopkeepers often prefer to remain closed on the days of important cricket matches. Although these demonstrations are reminiscent of the peripatetic provocations of Indian communal rioters (Jaffrelot 
1992), they are actually less informed by the 'model' of the Indian communal riot than by the local practice of 'cruising'. This practice, which implies driving at a snail's pace in congested streets with loud speakers blasting fancy tunes, was invented by American teenagers and popularized worldwide by George Lucas' American Graffiti. In Southall, cruising remained a popular activity amongst the local youth at the time of my fieldwork, neo-Bhangra competing with Gangsta Rap in CD-players. These playful exhibitions mostly took place on the Broadway, Southall's main artery, which links the suburb with central London (topographically, the Broadway is an extension of Oxford Street). The peculiar marketing techniques of its shopkeepers, who do not hesitate to open their stalls on the sidewalk, are reminiscent of South Asian conventions on the use of urban space and make the Broadway a cruiser's paradise, since 'the satisfaction of the cruiser grows with the number of heads that are turned and with the whispers that identify one or the other as a 'big guy' in one of Southall's two well-known 'gangs" (Baumann 1998). The provocations of local youth 'gangs', during religious festivals and important cricket matches, were inspired by these leisurely practices of cruising. The communal incidents which have taken place in Southall during these symbolic events are therefore irreducible to politics, the place of fun needing to be acknowledged in these aggressive assertions of a powerful Self. $^{9}$

'Gang' may not be the most appropriate term to define the 'local, mainly disorganized collective affiliations' (Bhatt 1997: 269) which appeared among deprived South Asian youths from east, west, northwest and southeast London, but also from the Midlands and the north, during the mid-1980s. Some of these 'gangs' were hardly organized and would only become semi-organized for specific events. In west and northwest London, however, these violent youth associations had a more permanent basis. Between the mid-1980s and the mid-1990s, the two main 'gangs' of the area were the Holy Smokes (which was mainly composed of young Sikh males) and the Tooti Nungs (which was mainly composed of young Hindu males but which acquired some associates from the local Caribbean communities). By the end of the decade, two new 'gangs' had emerged in the area: the Sher-e Punjab, exclusively composed of young Sikhs, and the Chalvey Boys, which was composed of Muslims. Although the formation of these 'gangs' took place along religious lines, 'the manifestation of gang activities is far more complex than ethnic or religious identification allows and refers us to syncretic associations between criminal activities, surveillance and sexual harassment of women, 'antiracist' formations, renunciation of patriarchal pedagogy and recreation of patriarchal tradition, as well as explicitly religious political identification' (Bhatt 1997: 269). The rivalry between the 'Asian gangs' of west and north-west London had indeed several components in it: geographical, communal and criminal. The conflict between the Holy Smokes and the Tooti Nungs was reminiscent of that between English and Irish labourers settled in Southall during the 1920s: the Holy Smokes came from the 'Old' part of Southall, built in the Late Victorian era, whereas the Tooti Nungs came from the 'New' part of the town, which grew between the 1920s and 1950s (Baumann 1998: 38). Religion was also used by these gangs to legitimate their violence against the 'other', during important cricket matches and religious festivals. In 1997, for instance, 90 people were arrested in Southall for carrying arms and public disorder. Regrettably, this year, Eid and Diwali had been celebrated the same day.

23 For the young racketeers, communal violence was a way to provoke a retaliation which would make their offer of protection more attractive. But Asian youth 'gangs' in Southall 
and Slough also fought for the control of ' atta', this Punjabi word for 'flour' here referring to heroin. It is this implication in drug dealing that brought discredit to these 'gangs'. By the end of the 1990s, the 'gangs' had lost their popularity. Violence did not come to an end but the 'gangs' were unsuccessful in their protection racket: people understood that their offer of protection had too high a cost and started seeing them as a menace, threatening communal relations and discrediting South Asians in the eyes of the British public. Indeed, during the 1990s, the 'Asian gang' was brought by the British media 'to the forefront of public concerns over crime, urban decay, poverty and civil unrest' (Alexander 2000: 229). This re-imagination of the 'Asian' community as a troublesome lot greatly upset its elder members, who had been satisfied with previous clichés on their 'unthreatening, law abiding and unproblematic' model minority (Alexander 2000: 15). The medias' constructions of Southall as a land of gangsters were also detrimental to local businesses by driving away potential investors.

Women were the most vocal in their opposition to the 'gangs', even if a handful of young females did join them to get away from oppressive indoor and poverty-stricken lives. During my fieldwork, women were my only interlocutors to mention the existence of communal tensions in Southall. And although some of my female interviewees saw communal tensions as a natural fact of life, whether in the subcontinent or abroad, most of them made 'the gangs' responsible for the deterioration of community relations in the neighbourhood. This critique of gang warfare can be explained by the symbolic violence of gang members towards women of their own community. As James Clifford has suggested, 'Life for women in diasporic situations can be doubly painful - struggling with the material and spiritual insecurities of exile, with the demands of family and work, and with the demands of old and new patriarchies' (Clifford 1997: 259). This is precisely what made the life of so many female Southallians a permanent hardship and it helps to explain why they rejected the 'protection' that the gangs offered to their 'sisters'. Through this 'protection', gang members were in fact trying to impose a new moral order to these women, who were becoming more emancipated through their work ${ }^{10}$ and/or through their contacts with British society. The neo-patriarchal project of the gangs, which was enunciated in the politically and culturally correct idiom of 'protection' and 'honour', was clearly detrimental to women's interests, as local feminists have suggested (Patel 1990). Yet, it was apparently supported by traditional elites. Religious authorities, in particular, implicitly supported the 'gangs', in which they found a natural ally in their own moralization project (Bhatt 1997: 269).

If cricket has been appropriated by the 'gangs' of west and northwest London, its communalization was never complete and the game has also inspired diasporic peacebuilders. Before India and Pakistan developed their 'cricket diplomacy' at the end of the $1990 \mathrm{~s}^{11}$, a few British 'Asians' thought of using cricket as a 'confidence building measure' between Indians, Pakistanis, Bangladeshis and Sri-Lankans residing in Britain. In the second half of the 1990s, for instance, the owner of the cash and carry network 'Bestway' financed cricket teams which recruited their players among Bestway's employees of Indian, Pakistani and Bangladeshi origin. The recent attempts at pacifying cricket in South Asia might inspire more initiatives of this kind in the future and the game could thus become a 'bridge of peace' in the diaspora. In any case, these conflictive interpretations of the game remind us that 'a sport is an embodied practice in which meanings are generated, and whose representation and interpretation are open to negotiation and contest' (MacClancy 1996: 4). 


\section{External events and local divisions: the implosion of the Indian diaspora in Southall}

If the boundaries between South Asian communities settled in Britain are constantly renegotiated, particularly amongst the youth of the second generation, their internal boundaries are also regularly questioned. In Southall, these fissiparous tendencies were vividly illustrated by the formation of a 'Sikh diaspora' during the 1980s, which detached itself from the larger' Indian diaspora' after the events of 1984. Until these critical events, the handful of Sikh nationalists exiled in Britain had not received much attention from the Sikh public at large. However, political upheavals in the Punjab provided overseas Khalistanis with a golden opportunity to mobilize their ethnic brethren. Indeed, the attack on the Golden Temple and the anti-Sikh pogroms of 1984 produced a 'moral shock' (Jasper \& Poulsen 1995: 498-9) among overseas Sikhs, by brutally upsetting their political attitudes and leading them to mobilize themselves in favour of their rediscovered homeland.

The demand for the creation of a Sikh state in India was first formulated in the 1940s, as a response to the Pakistan movement (Riar 1999). In the Punjab as in the diaspora, this demand was revived after operation Bluestar. It was then brandished as a symbolic weapon defying the Indian state but was also used to comfort a traumatized community. At a more political level, the demand for Khalistan helped the recently settled migrants to gain a political clout in their community, their transnational nationalist protest promoting them to the rank of local 'community leaders'. This success was only temporary, though. From the beginning, the Khalistan movement suffered from fissiparous tendencies. In India, Khalistani armed groups failed to coordinate their actions through the Panthic Committee, which suffered from internecine strife between the self-proclaimed guerilla commanders. Abroad, a myriad of organizations competed for the support of the Sikh diaspora and for its representation on the international scene. In Britain, for instance, five organizations claimed the status of sole representative of the panth: the Khalistan Council (founded in 1980 in Punjab but led from London by Dr. Jagjit Singh Chauhan); the Dal Khalsa (founded in Punjab in 1978 but divided between an Indian faction and a British one); the Babbar Khalsa (also founded in Punjab in 1978 and divided between a national and an international branch with little intercommunication); the International Sikh Youth Federation (ISYF, founded in 1984) and the World Sikh Organization (WSO, founded in New York in 1984 and soon operating from the US, Canada and, to a lesser extent, the UK).

Whether in the UK or in North America, the movement for Khalistan has always been a fragmented collection of self-styled leaders and opposite factions. Dominated numerically and politically by Jat militants (Gayer 2000), the Khalistan movement has suffered from the main feature of Jat political culture: the fragility of hierarchical ties and, hence, of factional affiliations. Among the Jats, as shown by anthropologist Joyce Pettigrew (1985), alliance to a faction prevails above obedience to a leader, and even the association with a certain faction is a matter subject to swift changes. Whether in the Punjab or in the diaspora, militants committed to the Khalistan movement on a highly subjective and often temporary basis, out of personal convictions or emotions rather than in a sign of devotion to the cause of Sikh sovereignty or in allegiance to a particular leader. 
29 If the symbolic and physical violence of the Indian state has contributed to the formation of a 'Sikh diaspora' (Axel 2001), Khalistani ethnic entrepreneurs have reinforced the internal cleavages of the global panth, which existed long before the Indian army launched its assault on the Golden Temple but which came back with a vengeance in the years following these critical events. Indeed, the events of 1984 initiated a moment of solidarity which contributed to the transcendence of caste affiliations. However, this moment of unity was short-lived and the hegemonic position of the Jats in the movement for Khalistan kept other castes at bay. In Britain, this was particularly true of the Ramgarhias, whose specific identity was reinforced by their 'twice migrants' status (Bhachu 1985). Most of them had relocated in the UK after their expulsion from East Africa. And since their arrival, they had organized separately from the Jats, building their own temples and forming their own associations. Although Ravidasi 'untouchables' did not share this migratory trajectory, they also remained outside the movement for Khalistan and organized on their own terms, around their own religious institutions, known as deras.

Far from being consensual, Khalistani attempts at building a Sikh diaspora around a nationalist agenda have thus met with a mitigated success and they ended up reinforcing the pluralism of overseas Sikh 'communities'. On a larger scale, it seems to me that South Asian communities settled in the UK have been going through a process of implosion which could be compared to the opening of a Russian nesting doll. The Indian diaspora, for instance, has given birth to antagonistic religious diasporas which, in turn, have imploded along caste lines. However, as Gerd Baumann (1998: 115) suggests, 'this process is not one of simple segmentary fission, of a 'majority community' falling apart. Rather, it increases the institutional repertoire while leaving intact the multiplicity of cross-cutting cleavages'. Moreover, as I have already suggested, attempts have been made at rebuilding the stacking doll. Since the return of the Punjab to normalcy, in the second half of the 1990s, some overseas promoters of Khalistan have reinvented themselves as Punjabi nationalists, trying to bridge the gaps between Punjabis of all caste and creed. On a supranational basis, South Asian youths from the upper classes have also tried to promote a pan-Asian ethnicity transcending linguistic and religious boundaries. Rather than being led by one structural trend, these processes of identity formation remain contested and contradictory, in a permanent dialectics of fission and fusion but also in a continuous arbitration between the various identity markers of nationality, language, caste and religion.

\section{Conclusion}

31 Looking at the relations between South Asian communities in a circumscribed area, such as West London, tells us a lot on the structural weaknesses of diasporas. The internal and external boundaries of these translocal ethnic groups are constantly questioned and challenged, often in opposite directions. Ethnic entrepreneurs challenging the dominant forms of identity politics which sustain the diaspora may be inward looking, emphasizing internal cleavages of the group to divide it or to 'cleanse' it from unorthodox elements. These challengers may also be outward looking, trying to bridge the gaps with other diasporic 'communities'. 'Diaspora is where constructed nationalisms come into contact' (Shukla 2005: 13) and the dialectics of fission and fusion is at work in every segment of Indian and Pakistani diasporic formations, as well as in their contact zones. It fashions 
the relations between and within these diasporas. It takes specific forms in each political locality, according to local equations of power and to the response of local state authorities. Thus, if an Indian, a Pakistani or even an Indo-Pakistani diaspora does exist, it is not as a stable and unitary 'transnational community' but rather as a plural society with flexible internal and external boundaries.

\section{BIBLIOGRAPHY}

Alexander, Clare E. (2000) The Asian Gang: Ethnicity, Identity and Masculinity, Oxford: Berg.

Axel, Brian Keith (2001) The Nation's Tortured Body: Violence, Representation and the Formation of a Sikh 'Diaspora', London \& Durham: Duke University Press.

Ballard, Roger (1999) 'Panth, Kismet, Dharm te Qaum: Continuity and Change in Four Dimensions of Punjabi Religion', in Pritam Singh \& Shinder Singh Tandhi (eds.), Punjabi Identity in a Global Context, Delhi: Oxford University Press, pp. 7-37.

Barrier, N. Gerald; Dusenbery, Verne (eds.) (1989) The Sikh Diaspora: Migration and the Experience beyond Punjab, Delhi: Chanakya.

Barth, Fredrik (1969) Ethnic Groups and Boundaries: The Social Organization of Culture Difference, London: Allen \& Unwin.

Bates, Crispin (ed.) (2001) Community, Empire and Migration: South Asians in Diaspora, Hyderabad: Orient Longman.

Baumann, Gerd (1998) [1996] Contesting Culture: Discourses of Identity in Multi-Ethnic London, Cambridge: Cambridge University Press.

Bhachu, Parminder (1985) Twice Migrants: East African Settlers in Britain, London: Tavistock.

Bhatt, Chetan (1997) Liberation and Purity: Race, New Religious Movements and the Ethics of Postmodernity, London: UCL Press.

Brown, Judith (2007) Global South Asians: Introducing the Modern Diaspora, Cambridge: Cambridge University Press.

Clifford, James (1997) Routes: Travel and Translation in the Late Twentieth Century, Cambridge: Harvard University Press.

Dufoix, Stéphane (1999) 'L'objet diaspora en questions', Cultures \& Conflits, 33-34, Spring-Summer, pp. 147-63.

Gayer, Laurent (1998) Diaspora indo-pakistanaise et régulation de la conflictualité à Londres et Paris, M.Phil thesis, Paris: Sciences Po.

Gayer, Laurent (2000) 'The Globalization of Identity Politics: the Sikh Experience', International Journal of Punjab Studies, 7(2), July-December, pp. 223-62.

Gayer, Laurent (forthcoming) 'La privatisation de la politique étrangère en Asie du Sud: l'exemple de la 'diplomatie du cricket' entre l'Inde et le Pakistan', Annuaire français de relations internationales 2006, Paris \& Bruxelles: La Documentation française \& Bruylant. 
Glazer, Nathan \& Moynihan, Daniel P. (1975) 'Introduction', in Nathan Glazer \& Daniel P. Moynihan (eds.), Ethnicity. Theory and Experience, Cambridge: Harvard University Press, pp. 1-26. Ghosh, Papiya (2007) Partition and the South Asian Diaspora: Extending the Subcontinent, London : Routledge.

Grewal, J.S. (1999) 'Punjabi Identity: a Historical Perspective', in Pritam Singh \& Shinder Singh Tandhi (eds.), Punjabi Identity in a Global Context, Delhi: Oxford University Press, pp. 41-54.

Hannerz, Ulf (2003) 'Several Sites in One', in Thomas Hylland Eriksen (ed.), Globalization: Studies in Anthropology, London: Pluto, pp. 18-38.

Jaffrelot, Christophe (1992) 'Les émeutes entre hindous et musulmans: essai de hiérarchisation des facteurs culturels, économiques et politiques', Cultures \& Conflits, 5, Spring, pp. 25-54.

Jaffrelot, Christophe (2003) 'For a Theory of Nationalism', Questions de recherche, 10, June.

Jasper, M. James; Poulsen, Jane D. (1995) 'Recruiting Strangers and Friends: Moral Shocks and Social Networks in Animal Rights and Anti-Nuclear Protests', Social Problems, 42(4), pp. 493-512.

Jayaram, Narayana (ed.) (2004) The Indian Diaspora: Dynamics of Migration, Delhi: Sage.

Khan, Shaharyar M. (2005) Cricket, a Bridge of Peace, Karachi: Oxford University Press.

Krishna, R. Gopal (1982) ‘Morons and Oxymorons', The Times of India, 16 January.

MacClancy, Jermy (1996) ‘Sport, Identity and Ethnicity’, in Jeremy MacClancy (ed.), Sport, Identity and Ethnicity, Oxford: Berg, pp. 1-20.

Malik, Rifat (1997) ‘West Side Story Asian Style’, The Evening Standard, 22 May.

Marienstras, Richard (1989) 'On the Notion of Diaspora', in Gérard Chaliand (ed.), Minority Peoples in the Age of Nation-States, London: Pluto Press, pp. 119-25.

Mohammad-Arif, Aminah (2000) 'A Masala Identity: Young South Asian Muslims in the US', Comparative Studies of South Asia, Africa and the Middle East, 20(1-2), pp. 67-87.

Nandy, Ashis (2000) [1989] The Tao of Cricket. On Games of Destiny and the Destiny of Games, Delhi: Oxford University Press.

Parekh, Bhiku et al. (eds.) (2003) Culture and Economy in the Indian Diaspora, London: Routledge.

Patel, Pragna (1990) 'Southall Boys', in Southall Black Sisters (ed.), Against the Grain: A Celebration of Survival and Struggle, London: Southall Black Sisters, pp. 43-54.

Pettigrew, Joyce (1985) Robber Noblemen. A Study of the Political System of the Sikh Jats, London: Kegan Paul.

Riar, Sukhmani (1999) 'Khalistan: The Origins of the Demand and its Pursuit Prior to Independence', in Pritam Singh \& Shinder Singh Tandhi (eds.), Punjabi Identity in a Global Context, Delhi: Oxford University Press, pp. 233-44.

Safran, William (1991) 'Diasporas in Modern Societies: Myths of Homeland and Return', Diaspora, 1 (1), Spring, pp. 83-99.

Schnapper, Dominique (2001) 'De l'Etat-nation au monde transnational: du sens et de l'utilité du concept de diaspora', Revue européenne des migrations internationales, 17(2), pp. 9-36.

Sheffer, Gabriel (2003) Diaspora Politics: At Home Abroad, Cambridge: Cambridge University Press. Sheffer, Gabriel (ed.) (1986) Modern Diasporas in International Politics, London: Croom Helm. 
Shukla, Sandhya (2005) [2003] India Abroad: Diasporic Cultures of Postwar America and England, Delhi: Orient Longman.

Shuval, Judith T. (2003) 'The Dynamics of Diaspora: Theoretical Implications of Ambiguous Concepts', in Rainer Münz \& Rainer Ohliger (eds.), Diasporas and Ethnic Migrants: Germany, Israel and Russia in Contemporary Perspective, London: Frank Cass.

Skinner, Elliott P. (1993) 'The Dialectic between Diasporas and Homelands', in Joseph E. Harris (ed.), Global Dimensions of the African Diaspora, Washington D.C.: Howard University Press, pp. 11-40.

Tatla, Darshan Singh (1999) The Sikh Diaspora: The Search for Statehood, London: UCL Press.

Verkaaik, Oskar (2004) Migrants and Militants: Fun and Urban Violence in Pakistan, Princeton: Princeton University Press.

Vertovec, Steven (2000) The Hindu Diaspora. Comparative Patterns, London: Routledge.

Vertovec, Steven (ed.) (1991) Aspects of the South Asian Diaspora, Delhi: Oxford University Press.

Werbner, Pnina (1996) “Our Blood is Green': Cricket, Identity and Social Empowerment among British Pakistanis', in Jeremy MacClancy (ed.), Sport, Identity and Ethnicity, Oxford: Berg, pp. 87-111.

Werbner, Pnina (2002) Imagined Diasporas among Manchester Muslims. The Public Performance of Pakistani Transnational Identity Politics, Oxford: James Currey.

\section{NOTES}

1. For a notable exception to this rule, see Bates (2001).

2. On trans-local fieldwork, see Ulf Hannerz (2003: 21).

3. For a notable exception, see Werbner (2002).

4. Interview with Veena Verma, Southall, 19/07/1999.

5. John McDonnell, of Irish origin, became the M.P. for Hayes and Harlington in 1997.

6. On the 'masala culture' of South Asians settled in the US, see Mohammad-Arif (2000).

7. In 1997, 10,5\% of the youths were unemployed in the Chalvey borough of Slough, cradle of the dreaded Chalvey Boys. In the Ealing borough where Southall is located, this rate was even higher, approaching $40 \%$. In Southall itself, $32 \%$ of the 'Pakistani' males and $16 \%$ of the 'Indians' were unemployed at the beginning of the 1990s (Malik 1997, Baumann 1998: 51).

8. Several incidents of vandalism did affect the 1996 World Cup in India, though. This was the case, in particular, during the match between India and Sri-Lanka which took place in Calcutta's Eden Gardens. But in the weeks which followed the incident, 30000 Indians sent letters of apologies for the turmoil to the Sri-Lankan government (Nandy 2000: xvii).

9. On the relation between fun, violence and nationalism, see Verkaaik (2004).

10. According to the 1991 Census, $74 \%$ of 'Pakistani' women and $87 \%$ of 'Indian' women living in Southall were employed (Baumann 1998: 52).

11. On Indo-Pakistani 'cricket diplomacy', see Gayer forthcoming. 


\section{ABSTRACTS}

The construction of an 'other' and the confrontation with this intimate enemy lies at the heart of identity politics. In diasporic environments, these constructions of the 'other' have two major attributes: their multiplicity and their volatility. Ethnic entrepreneurs have a wide range of options to propose an 'enemy' to their audience, hence their multiplicity. At the same time, social and political evolutions in the migrants' country of residence or in their home state make such politics of otherness highly contingent. The study of ethnic relations in diasporic environments is thus a difficult task and very little empirical material is presently available on this critical issue. This paper is an attempt to fill this gap, through an exploration of patterns of conflict and cooperation amongst South Asian residents of Southall, in West London. 